\title{
Contextualizando a Matemática por meio da Perspectiva Metodológica da Resolução de Problemas
}

\author{
Fernando Francisco Pereira* \\ Universidade Tecnológica Federal do Paraná \\ 86300-000, Cornélio Procópio, PR \\ fernandoutfcp@gmail.com \\ Iara Souza Doneze \\ Universidade Tecnológica Federal do Paraná \\ 86300-000, Cornélio Procópio, PR \\ iaradoneze@hotmail.com \\ Barbara Palharine \\ Universidade Tecnológica Federal do Paraná \\ 86300-000, Cornélio Procópio, PR
}

\begin{abstract}
RESUMO
A experiência aqui relatada faz parte da aplicação de uma atividade que visa proporcionar um contado com a Resolução de problemas, advindo do interesse por essa Tendência Matemática. A atividade foi direcionada pelos graduandos do curso de licenciatura em matemática da Universidade Tecnológica Federal do Paraná - Campus Cornélio Procópio.

Pensando nos objetivos básicos da problematização, onde os alunos são levados a discussão e de procedimentos para a resolução do problema, que vão desde a leitura e análise cuidadosa da situação, até a elaboração de procedimentos que envolvem simulações, tentativas, hipóteses, sendo esses os alicerces para tornar um sujeito critico apto a conviver em sociedade e com o seus avanços.

De acordo com os PCN's de Matemática:

A resolução de problemas possibilita aos alunos mobilizar conhecimentos e desenvolver a capacidade para gerenciar as informações que estão a seu alcance. (BRASIL, 1998).

O presente trabalho apresenta uma proposta pedagógica desenvolvida em duas horas aulas em uma turma de $8^{\circ}$ ano do ensino fundamental II de um colégio estadual, abordando o conteúdo de porcentagem, regra de três simples, conteúdos estes que segundo as diretrizes de leis e bases do Paraná, são abordados no $6^{\circ}$ e $7^{\circ}$ ano do ensino fundamental.

A atividade aplicada em sala consistia em uma problematização acerca do aquífero guarani que está localizado na região Centro-leste da América do Sul, abrangendo a região de residência dos alunos. O problema exigia dos alunos muita atenção e interpretação, pois haviam dados que estavam relacionados às questões propostas.

Durante a realização da atividade percebeu-se que os alunos enfrentaram obstáculos na leitura e interpretação da situação problema. A interpretação indevida levou-os ao insucesso na estruturação da situação problema, sendo assim percebemos que continham resoluções onde o aluno de inicio interpretou e estruturou de maneira correta, porem finalizou á atividade indevidamente, outros começaram o desenvolvimento mais desistiram de inicio, dizendo ser difícil resolver.
\end{abstract}

Houve questionamentos em relação ao resultado se o mesmo seria em porcentagem ou unidade de medida, ou então qual seria a unidade de tempo que o resultado deveria conter.

Pode-se notar que foram poucos os momentos onde os alunos discutiram a atividade, elaboram hipóteses ou se quer fizeram uma nova leitura. 
Tiramos por conclusão que os alunos não estão acostumados com metodologias diferenciadas em sala de aula, e quando estes se deparam com uma nova forma de ensino e aprendizagem, sentem uma grande insegurança, pois estão saindo de sua zona de conforto. Sendo assim sempre é necessário que o professor utilize novas metodologias para que os alunos possam se familiarizar e não ver a matemática simplesmente como um disciplina da qual apenas se reproduz o que está no livro didático.

Para Zuffi \& Onuchic:

A resolução de problemas pode colaborar para que haja alguma mudança na perspectiva da ação docente. Afinal sua utilização merece atenção por parte de todos os professores. (2007)

A perspectiva metodológica de resolução de problemas, traz uma problematização contextualizada de alguma forma da realidade do aluno, estimula a leitura e em certos casos responde a grande pergunta da maior parte dos alunos que é: Onde irei usar isso? Para que preciso saber isso?

Assim os alunos passam a ter uma nova visão sobre a matemática, e isso pode contribuir de forma satisfatória para o processo de ensino e aprendizagem, haja visto que se os alunos sentirem interesse pelo conteúdo a ser estudado a aprendizagem seria algo marcante e prazeroso a eles.

Palavras-chave: Resolução de Problemas; Ensino Fundamental

\section{Referências:}

[1] BRASIL. Parâmetros curriculares nacionais: matemática. Secretaria da Educação Fundamental. Brasília: MEC/SEF, 1998.

[2] SECRETARIA DE ESTADO DA EDUCAÇÃO DO PARANÁ. Diretrizes Curriculares da Educação Básica, Matemática - Paraná, 2008.

[3] ONUCHIC, L.L.R. \& ZUFFI, E. M. O ensino-aprendizagem de matemática através da Resolução de Problemas e os processos cognitivos superiores. Revista Iberoamericana de Matemática, 2007, 79- 97. 